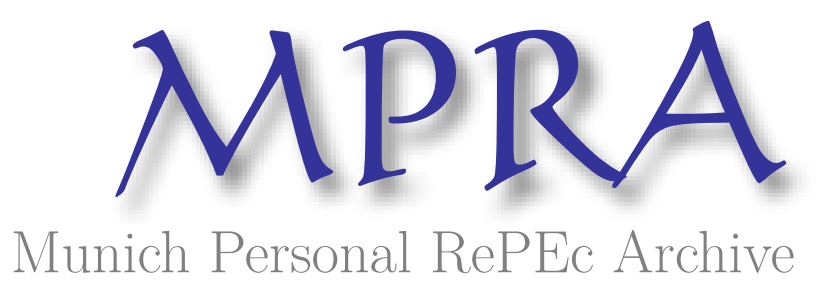

\title{
Indian bank efficiency and productivity changes with undesirable outputs:A disaggregated approach
}

Fujii, Hidemichi and Managi, Shunsuke and Matousek, Roman

2013

Online at https://mpra.ub.uni-muenchen.de/92657/

MPRA Paper No. 92657, posted 12 Mar 2019 08:51 UTC 
Indian bank efficiency and productivity changes with undesirable outputs:

A disaggregated approach

\begin{abstract}
:
The objective of this study is to examine technical efficiency and productivity growth in the Indian banking sector over the period from 2004 to 2011. We apply an innovative methodological approach introduced by Chen et al. (2011) and Barros et al. (2012), who use a weighted Russell directional distance model (WRDDM) to measure technical inefficiency. We further modify and extend that model to measure TFP change with NPLs. We find that the inefficiency levels are significantly different among the three ownership structure of banks in India. Foreign banks have strong market competitiveness in India and they pull the production frontier in a more efficient direction. SPBs and domestic private banks show considerably higher inefficiency. We conclude that the restructuring policy applied in the late 1990s and early 2000s by the Indian government has not had a long-lasting effect.
\end{abstract}




\section{Introduction}

In the last two decades empirical research on Indian bank efficiency and productivity has attracted a considerable attention among academics and practitioners. Numerous studies have been published on bank performance that include, for example, Casu et al. (2012), Das and Ghosh (2006), Sensarma (2006, 2008), Das and Shanmugam (2004), Kumbhakar and Sarkar (2003), who among others examine bank efficiency and productivity growth of the Indian banking sector, mostly during the 1990s and early 2000s.

Despite extensive and numerous research, we identify a gap in recent academic research on bank efficiency and productivity in India. In particular, there is a lack of recent empirical studies that analyze the changes within the Indian banking sector in the second half of the 2000s, i.e. after the liberalization and consolidation process. In addition, the Indian banking system faces the problem of deteriorating balance sheets because of the growing volume of non-performing loans (NPLs) and the direct impact of NPLs on bank performance has not yet been addressed in recent literature. We also try to provide a deeper and more profound analysis of how individual inputs and outputs affect bank efficiency and productivity. Such an analysis is important for policy-makers, since it can disclose the main shortcomings within the individual banks and the system as a whole. This important issue has been neglected in banking studies, see, for example, Barros et.al. (2012) and Assaf et. al. (2013). The analysis of NPLs helps to disclose and recognize the problems within the system that could lead to the implementation of an appropriate regulatory framework. These changes could restore sound and efficient functioning of the Indian banking sector.

We examine technical efficiency and productivity growth in the Indian banking sector over the period from 2004 to2011. In doing so, we apply an innovative methodological approach introduced by Chen et al. (2011) and Barros et al. (2012), who use a weighted Russell directional distance model (WRDDM) to measure the technical inefficiency of Indian 
banks. We further modify and extend the model by measuring also total factor productivity (TFP) change. The uniqueness and contribution of this approach lies in resolving technical difficulties involved in the empirical analysis of how to disaggregate and quantify the contribution that individual components (outputs/inputs) have on bank efficiency and TFP change. The model is based on directional distance function, which we estimate in linear form. This has the attractive advantage of easy computation and incorporates undesirable outputs into the model.

Thus, we disaggregate and quantify the impact not only of NPLs but all the individual inputs/outputs on bank efficiency and TFP change. This is a new element in studies on bank efficiency in general, and an important contribution to current research on Indian bank efficiency and productivity in particular. The attempt to examine bank efficiency and productivity growth in this way is reinforced by the rapidly increasing volume of NPLs on Indian bank balance sheets. Furthermore, contemporary research on bank productivity has focused so far on the decomposition of TFP into Technical Change (TECHCH) and Efficiency Change (EFFCH).

We summarize the contribution of this study as follows. First, we examine the nexus between NPLs and bank efficiency that allows us to quantify the impact of NPLs on bank efficiency. Secondly, we provide a comprehensive analysis of the effects of individual bank inputs/outputs on overall banking efficiency and productivity. The decomposition of total technical efficiency and TFP, TECHCH and EFFCH by taking into account the contribution of the individual inputs and outputs is a key contribution to current research on bank efficiency. Third, the empirical analysis is the first of its type applied to the Indian banking sector that examines bank efficiency and productivity changes after the extensive bank consolidation process in the 1990s and early 2000s. We examine the period from 2004 to 2011. Furthermore, we introduce the concept of firm "innovator" (Fare et al. 1994) into our 
analysis. We quantitatively identify the best practice that move the production frontier upward. The discussion about this concept is in Section 4. Finally, we outline the policy implications of our findings.

The remaining parts of this paper are organized as follows: Section 2 provides an overview of the Indian banking industry, highlighting all the recent trends and challenges. Section 3 provides an overview of the literature, focusing on all the current gaps and reinforcing the contributions of this study. Section 4 describes the model and method of estimation. Section 5 discusses the data set and empirical results. Section 6 summarizes findings and concludes.

\section{Indian Banking System: An Overview}

The banking system in India has undergone complex transformation over last five decades. The sector experienced several conflicting development phases. In the 1950s, free and relatively liberal banking was gradually nationalised. This process was started by the transformation of the Imperial Bank of India into the State Bank of India (SBI). SBI's main objective was gradually to take over additional private banks in order to introduce the imposed policy of administratively allocated credits into sectors like agriculture and small businesses. The banking sector has become severely repressed through strict entry controls, interest rate controls and reserve requirements, among others restrictions. Furthermore, the nationalization of the banking sector was extensive. Sixteen commercial banks were nationalised in 1969 and a further six in 1980.

The banks that currently perform business activities in India can be divided into the following groups: public-sector banks, which include also private capital that is, however, rather marginal, purely privately-owned banks and banks with foreign capital. Along with these banks there are also regional rural banks and co-operatives. 
Administrative regulation of the Indian banks substantially reduced competitivene pressures. In terms of total assets, the market share of state-owned banks was more than 90 per cent. Such a deformed market structure marginalized the activities of private and foreign commercial banks. The lack of market pressures and competition led to inefficient credit allocation by state-owned commercial banks. This was later reflected in the deterioration of bank balance sheets. Particularly, there has been an increase in the volume of NPLs, bank profitability dropped and consequently banks became undercapitalized.

In the 1980s, it became evident that the over-regulated and inefficient Indian banking system was not able to respond to the fast growing economy. This fact was recognised by Narasimham Committee reports in 1991 and 1998, see Narasimham (1991, 1998). The Committee addressed the main shortcomings of the Indian banking sector and outlined banking reforms. The Indian banking sector has undergone several important phases of restructuring in last two decades.

In the 1990s, the government recognised that structural, legal and institutional bank reforms were essential for further economic development. The Indian banking system has gradually been deregulated, opened to new domestic and foreign banks and formerly stateowned banks were partially privatised, recapitalised and consolidated. The stability of the state-owned banks has been undermined by an increase in NPLs. These key reforms were aimed at the improvement of bank competitiveness, performance and anchoring stability within the banking system. The changes focused on the deregulation of the banking sector, particularly credit control allocation along with interest rate control on deposit and loans. The banking sector was also gradually opened-up to new entrants - both private and foreign banks. An integral part of this reform was the extensive recapitalization of state-owned banks. Herd et al. (2011) indicate that overall INR 204 billion was spent on banking consolidation during the 1990s, which corresponds to 1.5 percent of GDP in 2009. 
The second stage of reforms reflected the recommendation of the second Narasinham Committee on Financial Sector Reforms in 1998. These changes were intended to restore the stability of the banking system through improved banking regulation, imposing the minimum standards on capital adequacy, increase competitiveness and efficiency. As a consequence of these measures, there has been a wave of mergers and acquisitions among banks. Some of these mergers and acquisitions were conducted on market principles but in many cases the government 'assisted' in this consolidation process.

Herd et al. (2011) argue that the government has to continue the recapitalization of the banking sector and that between 18 and 20 PSBs will require further financial assistance. As for the privately-owned banks it is also expected that additional capital is needed to stabilize particularly small-sized private banks. Herd et al. (2011) further show that the government prepared the provision of INR 165 billion for the recapitalization of PSBs in the 2010-2011 Budget. These resources are in addition to INR 31 billion spent in the period 2008-2009.

Although the bulk of poor quality assets on the balance sheets has been written off, new NPLs have been accumulated. This problem was reinforced by the fact that the provisions against NPLs were only 46 per cent in 2010 . The regulator responded to the low level of provision by increasing provisioning requirements to 70 per cent by the end of 2010 . It is evident that the current level of NPLs could eventually lead to systemic risk in the sector, unless the government does not step in. It is evident that the balance sheets of SPB have again gradually deteriorated, particularly in terms of outstanding loans.

\section{Literature Review}

In the following Section, we provide a brief overview of empirical studies on the performance of Indian banks. The second part of the review summarizes and outlines the current development of methodological research in estimating efficiency and productivity in 
general. And we show how our methodology contributes to the overall literature on bank efficiency and productivity measurements.

\subsection{Empirical research on Indian bank efficiency and productivity}

Since the second half of the 1990s, there has been extensive research that examines bank efficiency and productivity growth in Indian banking. Empirical research of the Indian banking sector can be divided into two main strands. First, studies that analyze bank efficiency and productivity changes, with particular attention on ownership structure. The second strand of literature examines the impact of consolidation, deregulation and restructuring processes on bank efficiency and productivity.

The first strand of empirical research is represented by Sarkar and Bhaumik (1998), Sarkaret et. al. (1998), Bhaumik and Dimova (2004), among others. These studies investigate whether the bank ownership structure had an effect on bank efficiency during and after the deregulation process that was initiated in the 1990s. In particular, they analyze how the different efficiency levels of state-owned banks differ from private domestic and foreign banks. They argue that there was no significant improvement in bank efficiency in the early stage of liberalization, i.e. from 1993 to 1995. Bhaumik and Dimova (2004) expand the period analyzed by covering the period from 1995 to 2001 . Their results show that domestic private and foreign banks performed better in 1995-1996 and then after the degree of divergence narrows between these two groups of banks and state-public banks (SPBs).

Sahoo and Tone (2009) in their study analyze profit changes within the Indian banking sector. They find, among other important results, that all three types of banks showed a recovering efficiency change trend after 2002. They describe this as an indication of the positive effects of structural changes on Indian banks' performance. Furthermore, they 
argue that output and resource allocation performances are weak in the segment of nationalized banks. Tabak and Tecles (2010) deploy the Bayesian stochastic frontier approach to test both cost and profit efficiencies in the Indian banking sector during the period from 2000 to 2006. Their results are in line with other studies on bank efficiency, i.e. SPBs became more efficient compared to domestic private and foreign banks. They argue that these results favour the current liberalization policy that opens the Indian banking sector. Thus, the openness of the sector to newcomers leads to increased competition and consequently domestic banks are forced to adopt best practices.

Recently, Sanyl and Shankar (2011) use a sample of Indian banks that covers the period from 1992 to 2004 . They split up the sample into the pre- and post-1998 period. The results indicate that the productivity gap among different groups of banks increased after 1998. Surprisingly, the private domestic banks were the worst performers.

The second strand of research represented, for example, by Bhattacharryya et al. (1997), who examine TFP changes within SPBs over the period from 1970 to1992. Such a relatively long period provides a detailed analysis of bank behaviour during the different phases of banking sector development. They argue that the institutional changes, such as economic liberalization and deregulation of the financial sector, positively affected TFP annual growth, which increased from 2 to 7 percent by the end of the analyzed period. Kumbhakar and Sarkar (2003) conduct a similar investigation for the period from 1985 to 1996. They show that SPBs did not respond so positively to the deregulation process as private domestic and foreign banks.

Das and Kumbhakar (2012) contribute further to research on bank efficiency and productivity. Their study applies an innovative methodological concept by capturing the qualitative aspects of inputs/outputs in modelling bank efficiency and productivity. The study covers the period from 1996 to 2005. The results indicate that there was an improvement in 
bank efficiency levels from 61 per cent to 72 per cent in 1996 and 2005 respectively. In addition, they show that the improvement in bank efficiency levels in the SPBs segment was higher compared to private banks. TFP growth was above 3.5 percent per annum over the examined period. The driving forces behind TFP growth were technical progress and technical efficiency.

The most recent study by Casu et al. (2013) examines the impact of regulatory reform on productivity growth and its components for Indian banks from 1992 to 2009 . They argue that productivity growth is driven mainly by technological progress. In addition, their results indicate that different ownership types react differently to changes in the operating environment. The result unambiguously indicates that foreign banks become increasingly dominant and their production technology becomes the best practice in the industry in India.

\subsection{Bank performance with undesirable outputs: Methodological concepts}

Despite the fact that NPLs are important determinants affecting bank performance there have not been any studies that integrate or examine the role of NPLs on overall bank efficiency and performance.

Assaf et al. (2013) shows that NPLs have to be incorporated in the production process, otherwise the results are biased. For example, when a standard estimation of bank performance is considered, i.e. without including NPLs directly in the model, then a high performing bank is not necessarily better than other banks, as it might be doing that at the expense of producing a high percentage of undesirable outputs. Thus, a production process must be clearly defined based on both desirable and undesirable outputs; using only desirable outputs will fail to credit a bank for its effort to reduce undesirable outputs (Fernandez et al. 2002). 
There has been an expansion in the range of methodological approaches to empirical research on performance measurement models with undesirable outputs. Most of these studies have been published in the field of environmental and energy research: Färe and Grosskopf (2010), Färe et al.(2005), Zhou et al. (2007), among others. Färe and Lovell (1978) argue that to measure technical efficiency relative to an isoquant rather than to an efficient subset can lead to the identification of a unit as being technically efficient when it is not. Even recent studies show that non-radial efficiency measures have a higher discriminating power in evaluating the efficiencies of DMUs, for example, Fukuyama and Weber (2009), Chen at al. (2011) and Barros et al. (2012), among others.

However, research studies that estimate bank performance do not include in their models undesirable output NPLs as a part of the production process. NPLs are considered as a control variable in the specified efficiency function see, for example, Mester (1996), Berger and Mester (1997) among others. Alternatively, NPLs measure management behaviour through bad luck or bad management hypotheses introduced by Berger and De Young (1997), Williams (2004).

In the seminal paper, Berg et al. (1992) incorporate the quality of bank assets directly into the model. They measure bank productivity in the Norwegian banking sector by applying the Malmquist index. The quality of loan evaluations is measured through loan losses that are used as an additional output in the model. This type of research has only recently been extended by Park and Weber (2006), who reopened the issue of NPLs and their inclusion in the production process. Park and Weber (2006) treat NPLs as an undesirable output for measuring bank efficiency and productivity of Korean banks for the period from 1992 to 2002. NPLs are an undesirable by-product output arising from the production of loans. The methodological approach is based on the directional technology distance function and allows controls for loan losses that are an undesirable by-product arising from the production of 
loans. Fukuyama and Weber (2008) then investigate efficiency and shadow prices for NPLs within Japanese commercial banks during the period from 2002 to 2004 . They concluded that NPLs should not be ignored in the efficiency analysis of Japanese banks. Barros et al. (2012) show that the implementation of NPLs into the efficiency model provides bank managers and regulators with an additional dimension in their decision-making process since they affect bank efficiency. The most recent study by Assaf et al. (2013) confirms Barros et al's (2012) results, showing that NPLs have to be integrated in the model.

It is evident that the performance of Indian banks has been extensively analyzed from different perspectives. However, none of these studies accounts directly in their model for an undesirable output, i.e. NPLs. In addition, our study provides a unique analysis of the individual factors of the production process and the final outputs. Thus, we open a black-box by being able to distinguish the contribution of the individual production factors and final outputs. Finally, we use a dataset that enables us to examine the recent trend in the Indian banking sector.

\section{Methodology}

This study measures productivity change in the Indian banking sector. We apply the weighted Russell directional distance model (WRDDM) to measure productive inefficiency using production technology following Chen et al. (2011) and Barros et al. (2012). They proposed a measure based on directional distance function, which is evaluated in linear form, and hence possesses the attractive advantages of easy computation and easy extension of incorporating the additional undesirable outputs into the programming problems. Our main objective is to understand the impact of the changes of individual inputs/outputs on bank productivity. This is a novelty in contemporary research on bank efficiency and productivity. 


\subsection{Weighted Russell directional distance model (WRDDM)}

Let inputs be denoted by $x \in R_{+}^{N}$, good outputs by $y \in R_{+}^{M}$, and undesirable outputs by $b \in R_{+}^{L}$. The directional distance function seeking to increase the desirable outputs and decrease the undesirable outputs and inputs directionally can be defined by the following:

$$
\overrightarrow{\mathrm{D}}(x, y, b \mid \mathrm{g})=\sup \{\beta:(x+\beta \mathrm{g}, y+\beta \mathrm{g}, b+\beta \mathrm{g}) \in T\}
$$

Where the vector $\mathrm{g}=\left(-\mathrm{g}_{x}, \mathrm{~g}_{y},-\mathrm{g}_{b}\right)$ determines the directions in which inputs, desirable outputsand undesirable outputs are scaled. The technology reference set $T=\{(x$, $y, b): x$ can produce $(y, b)\}$ satisfies strong disposability of desirable outputs and inputs, and weak disposability of undesirable outputs.

Suppose there are $\mathrm{j}=1,2, \cdots, \mathrm{k}, \cdots$, Jfirms in the dataset. Each firm uses inputs $x=$ $\left(x_{1}, x_{2}, \cdots, x_{N}\right) \in R_{+}^{N}$ to jointly produce desirable outputs $y=\left(y_{1}, y_{2}, \cdots, y_{M}\right) \in R_{+}^{M}$ and undesirable outputs $b=\left(b_{1}, b_{2}, \cdots, b_{L}\right) \in R_{+}^{L}$. The WRDDM for inefficiency calculation of firm $k$ can be described as follows:

$$
\overrightarrow{\mathrm{D}}(\mathrm{x}, \mathrm{y}, \mathrm{b} \mid \mathrm{g})=\operatorname{maximize}\left(\frac{1}{N} \sum_{n=1}^{N} \beta_{n}^{k}+\frac{1}{M} \sum_{m=1}^{M} \beta_{m}^{k}+\frac{1}{L} \sum_{l=1}^{L} \beta_{l}^{k}\right)
$$

subject to

$$
\begin{aligned}
& \sum_{j=1}^{J} z_{k} y_{m j} \geq y_{m k}+\beta_{m}^{k} \mathrm{~g}_{y m k} \\
& \sum_{j=1}^{J} z_{k} b_{l j}=b_{l k}+\beta_{l}^{k} \mathrm{~g}_{b l k} \\
& \sum_{j=1}^{J} z_{k} x_{n j} \leq x_{n k}+\beta_{n}^{k} \mathrm{~g}_{x n k} \\
& Z_{j} \geq 0, \quad j=1,2, \cdots, k, \cdots, J
\end{aligned}
$$


where $\beta_{m}^{k}, \beta_{l}^{k}$, and $\beta_{n}^{k}$ are the individual inefficiency measures for desirable outputs, undesirable outputs, and inputs, respectively. $Z_{k}$ is the intensity variable to shrink or expand the individual observed activities of firm $k$ for the purpose of constructing convex combinations of the observed inputs and outputs. To estimate productivity change indicators, we set directional vectorg $=\left(-\mathrm{g}_{x n k}, \mathrm{~g}_{y m k},-\mathrm{g}_{b l k}\right)=\left(-x_{n k}, y_{m k},-b_{l k}\right)$; , the WRDDM is shown as follows:

$$
\overrightarrow{\mathrm{D}}\left(x_{k}, y_{k}, b_{k} \mid \mathrm{g}\right)=\operatorname{maximize}\left(\frac{1}{N} \sum_{n=1}^{N} \beta_{n}^{k}+\frac{1}{M} \sum_{m=1}^{M} \beta_{m}^{k}+\frac{1}{L} \sum_{l=1}^{L} \beta_{l}^{k}\right)
$$

subject to

$$
\begin{aligned}
& \sum_{j=1}^{J} z_{k} y_{m j} \geq y_{m k}\left(1+\beta_{m}^{k}\right) \\
& \sum_{j=1}^{J} z_{k} b_{l j}=b_{l k}\left(1-\beta_{l}^{k}\right) \\
& \sum_{j=1}^{J} z_{k} x_{n j} \leq x_{n k}\left(1-\beta_{n}^{k}\right) \\
& Z_{j} \geq 0, \quad j=1,2, \cdots, k, \cdots, J
\end{aligned}
$$

This type of directional vector assumes that an inefficient firm can decrease productive inefficiency while increasing desirable outputs and decreasing undesirable outputs and/or inputs in proportion to the initial combination of actual inputs and outputs.

One of the strong points of the WRDDM is that it is able to determine each variable's contribution effect for inefficiency. This contribution effect cannot be determined in conventional productive inefficiency analysis. The contribution effects enable us to discuss how and why such firms successfully decreased their productive inefficiency. 


\subsection{TFP change decomposition and identification of innovator}

In order to analyze changes in efficiency over time, aggregated indices such as the Malmquist Index and Luenberger Productivity Indicator have been developed (Chambers, 1998). They are derived from the efficiency scores of production frontier models. These productivity indices are measures of total factor productivity, when the efficiency score comes from economic production frontier models. TFP includes all categories of productivity changes and can be decomposed further to provide a better understanding of the relative importance of various components, including Technical Change and Efficiency Change (Färe et al. 1994). Technical Change measures shifts in the production frontier, so-called frontier shift. Efficiency Change measures changes in the position of a production unit relative to the frontier, the so-called catching-up factor.

We employ the Luenberger Productivity Indicator as a TFP measure because the Luenberger Productivity Indicator is believed to be more robust than the widely used Malmquist Index (Chambers et al., 1998). Change in the Luenberger Productivity Indicator (TFP) is further broken down into technical change and efficiency change. TFP is computed with the results of the WRDDM and derived as follows:

$$
\begin{aligned}
& \mathrm{TFP}_{\mathrm{t}}^{\mathrm{t}+1}=\frac{1}{2}\left\{\overrightarrow{\mathrm{D}}^{\mathrm{t}+1}\left(x_{k}^{t}, y_{k}^{t}, b_{k}^{t}\right)-\overrightarrow{\mathrm{D}}^{\mathrm{t}+1}\left(x_{k}^{t+1}, y_{k}^{t+1}, b_{k}^{t+1}\right)+\overrightarrow{\mathrm{D}}^{\mathrm{t}}\left(x_{k}^{t}, y_{k}^{t}, b_{k}^{t}\right)-\overrightarrow{\mathrm{D}}^{\mathrm{t}}\left(x_{k}^{t+1}, y_{k}^{t+1}, b_{k}^{t+1}\right)\right\} \\
& \mathrm{TECHCH}_{\mathrm{t}}^{\mathrm{t}+1}=\frac{1}{2}\left\{\overrightarrow{\mathrm{D}}^{\mathrm{t}+1}\left(x_{k}^{t}, y_{k}^{t}, b_{k}^{t}\right)+\overrightarrow{\mathrm{D}}^{\mathrm{t}+1}\left(x_{k}^{t+1}, y_{k}^{t+1}, b_{k}^{t+1}\right)-\overrightarrow{\mathrm{D}}^{\mathrm{t}}\left(x_{k}^{t}, y_{k}^{t}, b_{k}^{t}\right)-\overrightarrow{\mathrm{D}}^{\mathrm{t}}\left(x_{k}^{t+1}, y_{k}^{t+1}, b_{k}^{t+1}\right)\right\} \\
& \mathrm{EFFCH}_{\mathrm{t}}^{\mathrm{t}+1}=\overrightarrow{\mathrm{D}}^{\mathrm{t}}\left(x_{k}^{t}, y_{k}^{t}, b_{k}^{t}\right)-\overrightarrow{\mathrm{D}}^{\mathrm{t}+1}\left(x_{k}^{t+1}, y_{k}^{t+1}, b_{k}^{t+1}\right) \\
& \mathrm{TFP}_{\mathrm{t}}^{\mathrm{t}+1}=\mathrm{TECHCH}_{\mathrm{t}}^{\mathrm{t}+1}+\mathrm{EFFCH}_{\mathrm{t}}^{\mathrm{t}+1}
\end{aligned}
$$

where $x_{\mathrm{t}}$ represents the input for year $\mathrm{t}, x_{\mathrm{t}+1}$ is the input for year $\mathrm{t}+1, y_{\mathrm{t}}$ is the desirable output for year $\mathrm{t}$, and $y_{\mathrm{t}+1}$ is the desirable output for year $\mathrm{t}+1$. $b_{\mathrm{t}}$ is the undesirable output for year $\mathrm{t}$, and $b_{\mathrm{t}+1}$ is the undesirable output for year $\mathrm{t}+1 . \overrightarrow{\mathrm{D}}^{\mathrm{t}}\left(x_{k}^{t}, y_{k}^{t}, b_{k}^{t}\right)$ is the 
inefficiency score of year $\mathrm{t}$ based on the frontier curve in year t. Similarly, $\overrightarrow{\mathrm{D}}^{\mathrm{t}+1}\left(x_{k}^{t}, y_{k}^{t}, b_{k}^{t}\right)$ is the inefficiency of year $t$ based on the frontier curve in year $t+1$. The TFP score indicates the productivity change as compared with the benchmark year. The TFP includes all categories of productivity change, which can be broken down into Technical Change (TECHCH) and Efficiency Change (EFFCH) as equation (15).

Here, we break down TFP using the inefficiency score of input, desirable output, and undesirable output variables' contribution effect for inefficiency. The detailed breakdown of TFP is discussed in Appendix 1.

$$
\begin{aligned}
& \mathrm{TFP}_{\mathrm{t}}^{\mathrm{t}+1}=\mathrm{TFP}_{\mathrm{t}, x}^{\mathrm{t}+1}+\mathrm{TFP}_{\mathrm{t}, \mathrm{y}}^{\mathrm{t}+1}+\mathrm{TFP}_{\mathrm{t}, \mathrm{b}}^{\mathrm{t}+1} \\
& \mathrm{TECHCH}_{\mathrm{t}}^{\mathrm{t}+1}=\mathrm{TECHCH}_{\mathrm{t}, x}^{\mathrm{t}+1}+\mathrm{TECHCH}_{\mathrm{t}, \mathrm{y}}^{\mathrm{t}+1}+\mathrm{TECHCH}_{\mathrm{t}, \mathrm{b}}^{\mathrm{t}+1} \\
& \mathrm{EFFCH}_{\mathrm{t}}^{\mathrm{t}+1}=\mathrm{EFFCH}_{\mathrm{t}, \mathrm{t}}^{\mathrm{t}+1}+\mathrm{EFFCH}_{\mathrm{t}, \mathrm{y}}^{\mathrm{t}+1}+\mathrm{EFFCH}_{\mathrm{t}, \mathrm{b}}^{\mathrm{t}+1}
\end{aligned}
$$

$\mathrm{TFP}_{\mathrm{t}, x}^{\mathrm{t}+1}$ represents a contribution effect of input variables for TFP change. $\mathrm{TFP}_{\mathrm{t}, \mathrm{y}}^{\mathrm{t}+1}$ represents a contribution effect of desirable output variables for TFP change. $\mathrm{TFP}_{\mathrm{t}, b}^{\mathrm{t}+1}$ represents a contribution effect of undesirable output variables for TFP change.

TECHCH for any particular firm only represents the shift in the production frontier from the viewpoint of that firm. A value of TECHCH does not necessarily imply which firm did actually shift the frontier line in a more desirable direction. Thus, in order to specify the firms that were shifting the frontier line, so-called "innovators" (see Färe et al., 1994), the following three conditions are required to be satisfied for a given firm.

By using the WRDDM result, we can distinguish the technological innovator from the three points of view, which are desirable output, undesirable output, and input. For example, technological innovator of input $(x)$ and desirable output $(y)$ needs to fulfil the following conditions. The technological innovator of input and desirable output (Innovator $x, y$ ) achieves 
more efficient input use and desirable output production from $t$ year to $t+1$ year: In Appendix 2, we explain how we identify the "innovator".

Furthermore, the technological innovator of undesirable output reduces needs to fulfil the following conditions. The technological innovator of undesirable output performance (Innovator $b$ ) achieves more efficient undesirable output management from $t$ year to $t+1$ year.

\section{Data and empirical results}

\subsection{Data}

The dataset used in this study was obtained from the Indian Banks' Association and the Reserve Bank of India. The data comprises the inputs and outputs variables for the period 2004 to 2011. All data were deflated to 2010 prices. We construct aggregate efficiency and bank productivity measures. Banks are assumed to produce three outputs: other earning assets, customer loans and bad loans by using three inputs: labour, deposits and premises. Table 1 provides us with the statistical summary of our sample.

There are several approaches to modelling the bank production process. The standard methods are the intermediation and production approaches. Under the intermediation approach, banks use purchased funds together with physical inputs to produce various assets (measured by their value). According to the production approach, banks use only physical inputs, such as labour and capital, to produce deposits and various assets (measured by the number of deposit and loan accounts at a bank, or by the number of transactions for each product). We adopt the intermediation approach to model bank production and consider banks to be intermediaries of financial services that purchase input in order to generate earning assets (Sealey and Lindley, 1977). Berger and Humphrey (1997) suggest the 
intermediation approach is best suited for evaluating bank efficiency, whereas the production approach is appropriate for evaluating the efficiency of bank branches.

\section{<Insert Table 1>}

We present our results in two parts. First, we report results for bank inefficiency and its components. The second part then focuses on the detailed analysis of productivity growth and its drivers.

\subsection{Bank inefficiency}

We report results for technical efficiency using the assumption of a constant return to scale (CRS). We present the results in Tables 2 and 3. Table 2 reveals the average inefficiency scores for individual inputs and outputs, including NPLs, and total technical inefficiency. We cannot confirm an improvement in bank efficiency over the examined period. We observe an abrupt increase in bank inefficiency after 2004 that continues until 2009, with an exception for 2007-2008. Then, bank inefficiency decreases to 58.8 and 57.5 per cent in 2010 and 2011 respectively.

Furthermore, our methodological approach allows us to open the black-box and examine the individual drivers behind bank inefficiency. In Table 2, we report the inefficiency levels of individual inputs/outputs. We see that the inefficiency scores for employees and deposits are high in 2004 but that they gradually decrease over the examined period. The inefficiency score of employees' contribution is 55 per cent in 2004 and reduces to only 9 per cent in 2011. This can be seen as a positive sign that indicates the successful implementation of bank restructuring policies. We obtain similar results for deposits. As for physical capital, the inefficiency levels remain low, which indicate that banks utilized their physical capital in more efficient ways. 
On the other hand, the inefficiency levels of individual outputs are rather high. This is particularly evident for the categories of other earning assets (OEA) and NPLs. The contribution of NPLs to bank inefficiency is also quite volatile. The inefficiency levels of NPLs improved until 2010, but then the inefficiency level of NPLs increased by 25 percentage points. This deterioration corresponds with the current situation in Indian banking, when NPLs become a problem particularly for SPBs. Our results further indicate that banks have a large scope for improvement by expanding their business activities in the segment of OEA. The estimated inefficiency levels for OEA remain very high. This might be improved by a further deregulation process that would allow banks to be involved also in other business activities apart from providing standard lending.

<Insert Table 2>

As we discuss in Section 2, there exist institutional and operational differences among Indian banks. To examine the differences in terms of their performance we divide banks into three groups according to their ownership structure: national banks, private domestic banks and foreign banks. Such a classification corresponds with the classification used by the Reserve Bank of India.

Table 3 then displays the individual inefficiency levels across these three groups. The bank efficiency levels of SPBs do not improve until 2009 despite the expensive consolidation programme introduced by the government. However, bank inefficiency again declines in 2011. In this year, the bank inefficiency score reaches the level of 66.9 per cent. This improvement corresponds with changes along with the individual levels of inputs/outputs inefficiencies. Inefficiency levels for deposits and employees on the average remain higher compared with private and foreign domestic banks. We further observe that the inefficiency 
levels of individual inputs gradually decline over the period. This positive trend indicates that the applied restructuring and liberalization policies that enhanced competitiveness eventually improved bank efficiency.

As for the second group, i.e. private domestic banks, we may see the similar trajectory of bank inefficiency levels. The inefficiency levels are lower compared to SPBs. This is even more striking in the foreign bank segment. The domestic bank group reports lower overall inefficiency levels that correspond with the inefficiency levels of individual inputs/outputs. We confirm that the ownership structure is an important determinant for bank performance.

As for the output inefficiency scores, the presented results convincingly confirm that the consolidation of banks' balance sheets in terms of NPLs was successful across all Indian banks. The inefficiency levels of NPLs considerably decreased over the period from 2009 to 2010. NPLs had only a marginal effect on bank inefficiency. However, the results for 2011 show an increase in overall bank inefficiency levels. That is accompanied by an increase in NPL inefficiency. Such a trend may indicate continuing problems with loans quality.

\section{$<$ Insert Table 3>}

Next, we examine whether the average inefficiency scores are statistically different among the three analyzed bank groups. We apply the Kruskal-Wallis test that is a general alternative to the nonparametric method of two-sample t-test. Based on the results of the test we reject the null hypothesis of equal inefficiency across these three bank groups. In Table 4, the results show that inefficiency scores are statistically different across the bank groups. It is evident that, apart from fixed assets that are statistically significant at a 5 percent level, the remaining variables are strongly significant at a 1 percent level. 
<Insert Table 4>

\subsection{TFP growth}

Next, we analyze results for TFP growth. TFP changes are broken down into Technical Change (TECHCH) and Efficiency Change (EFFCH). TECHCH shows shifts in the production frontier, while EFFCH measures changes in the position of a production unit relative to the frontier. Figures 1, 2 and 3 show the accumulative changes of TFP, TECHCH and EFFCH indicators from 2004 to 2011 . We set 2004 as the baseline year (All indicators are zero in 2004).

A positive TFP shows that the Indian banking sector achieved technological progress over the entire analyzed period. The cumulative TFP growth is 29.6 percent, which indicates an average growth of more than 4 percent. This is higher than the recently reported TFP in China by Chang et al. (2012), which show that the average TFP growth is 3.85 percent. In Figure 1, we report the individual drivers of TFP. We identify, in the first half of our analysis, that labour force savings and the use of fixed assets contribute to positive TFP changes. Deposits show a negative impact on TFP growth although at the marginal level of 0.01 per cent. As for outputs, the main factors behind the growth are NPLs and loans. However, we observe a different pattern from 2008, when NPLs have a negative impact on TFP. The standard decomposition of TFP into Technical Change (TECHCH) and Efficiency Change $(\mathrm{EFFCH})$ provides a further insight into the factor behind TFP changes.

From Figure 2 we observe that the cumulative TECHCH growth changes by 11.9 percent. Thus, Indian banks reports technological progress over the analyzed period. The main factors that shifted the production frontier are the use of deposits and labour costs that is reinforced by NPLs. Figure 3 shows the negative EFFCH during the period from 2004 to 2009. This negative growth is caused primarily by OEA and loans. Thus, TFP growth is 
driven until 2009 by positive TECHCH growth. After that, it is evident that the Indian banks are getting closer to the efficiency frontier. The particular drivers behind the positive impact on EFFCH are fixed assets, employees and the management of NPLs. However, as we see from Figures 2 and 3, the efficient management of NPLs did not offset the negative impact of NPLs on the TECHCH indicator. The effect of other earning assets on TFP growth reflects output expansion caused by shifts in the production frontier. However, other earning assets have a largely negative impact on EFFCH that is not fully offset by TECHCH.

\author{
$<$ Insert Figure 1> \\ $<$ Insert Figure 2> \\ <Insert Figure 3>
}

Table 5 provides an overview of the average values of the disaggregated factors of TFP, TECHCH and EFFCH for all three bank groups. As we see SPBs and domestic private banks show the positive TFP change. The foreign banks then report negative TFP growth. A further break down provides the detailed contribution of the individual factor to TFP growth and TECHCH and EFFCH indicators among the analyzed groups.

As for TFP growth, it is surprising that foreign banks over the analyzed period show productivity regress compared to SPBs and private domestic banks. We see that NPLs have a negative impact on TFP growth in the private and foreign bank segments. This result represents a treatment of NPLs that is more inefficient in 2011 compared to 2004. Additionally, NPLs negatively affect the TECHCH indicator for foreign banks. Thus, the productive frontier line is shifted more undesirable direction due to bad NPL treatment by foreign banks. 
$<$ Insert Table 5>

Finally, we introduce in our study the concept of firm "innovator" (Fare et al. 1994) that allows us to identify those banks that shift the production frontier. Table 6 identifies innovator banks over the analyzed period. As we can see, the technical progress of foreign banks acts as a driver that pushes production frontiers in the Indian bank sector. We can also confirm that foreign banks satisfy the condition of being innovators for both, i.e., input and output use, and NPL treatment. However, there is no shift to more desirable direction in the production frontier by foreign banks after 2009. Instead national and domestic banks take over the lead.

$<$ Insert Table 6>

\section{Conclusion}

This paper analyzes recent changes in bank efficiency and productivity growth in the Indian banking sector. The study contributes to ongoing empirical research on Indian banking see, for example, Das and Kumbhakar (2012), Casu et al. (2012), Tabak and Tecles (2010), among others. In addition, we apply an innovative methodological approach that extends recent research studies on bank efficiency and productivity, which includes Barros et al. (2012), Chang et al. (2012), Fukuyama and Sekitani (2012). We measure the effect of individual inputs and outputs to the overall bank performances and estimate the individual drivers of productivity growth. We also introduce the so-called "innovator" based on Färe et al. 1994. This is a new feature in studies on bank efficiency and productivity

We may summarize our results and contributions as follows. We find that the inefficiency levels are significantly different among the three ownership structures of Indian 
banks. We show that foreign banks have strong market competitiveness in India and they pull the production frontier in a more efficient direction. SPBs and domestic private banks show considerably higher inefficiency. The disaggregated bank inputs and outputs identify that, in particular, management of labour forces, other earning assets, and NPLs are the main factors contributing to bank inefficiency. Although our results suggest employee management in SPBs and domestic private banks has been improving more rapidly than in foreign banks. Furthermore, our results indicate that the Indian banking sector as a whole diverges to higher technical efficiency in 2011 but we cannot confirm if this is an occasional event or trend. Therefore, further examination is needed to confirm it.

The strong position of foreign banks in our findings contradicts earlier studies that used the data sample only for the 1990s and early 2000s (Kumbhakar and Sarkar (2003), Das and Ghosh (2006), Sanyal and Shankar (2011)). The previous research suggests that SPBs and private domestic banks operate more efficiently than foreign banks. Our results, however, indicate that SPBs failed to take advantage of the consolidation and restructuralization process that was strongly supported by the Indian government in the late 1990s. We argue that the improvement of SPBs in the 1990s and the early 2000s was rather temporary and SPBs now face again the problem of deteriorating balance sheets and poor management compared with established foreign banks. Casu et al's 2012 paper that uses a more recent dataset corresponds with our findings.

If we analyze productivity growth of the Indian banks we find that TFP growth has not improved significantly over the period from 2004 to 2011. The disaggregation of TFP into TECHCH and EFFCH shows that the production frontier actually shifted down from 2008. These results are consistent with Casu et al. (2013) who also find that the technological frontier shift is mainly caused by the performance improvement in the foreign bank group. Kumbhakar and Sakar (2003) pointed out that TFP growth was rather moderate in the 1990s 
and the sector showed signs of over-employment. Similar conclusions are presented again by Das and Kumbhakar (2012), who argue that Indian labour market inflexibility is a typical barrier to reform. We show that this issue has been partially resolved in the SPB segment in the second half of the 2000s.

The results presented unambiguously indicate that policy-makers and regulators need to address the continuing problems of mounting NPLs. We show that NPLs cause technological regress and this issue has to be addressed by Indian Banks. This result is most probably due to the traditional problems that still face Indian banks and affect their efficiency and productivity, which include factors such as the high percentage of NPLs, poor restructuring, management failings and the lack of market power.

We conclude that the restructuring policy applied in the late 1990s and early 2000s by the Indian government has not had a long-lasting effect in terms of improved efficiency and TFP growth, particularly in the SPB segment and further steps have to be taken by policymakers in order to fully restore the Indian banking system. Our findings support the recent analysis published by Herd et al. (2011).

\section{Reference}

Assaf, A. G., Matousek, R., Tsionas, E.G., 2013. Turkish bank efficiency: Bayesian estimation with undesirable outputs. Journal of Banking and Finance 37, 506-517.

Barros, C.P., Managi, S., Matousek, R., 2012. The technical efficiency of the Japanese banks: Non-radial directional performance measurement with undesirable output. Omega, $40,1-8$.

Berg, S.A., Forsund, F.R., Jansen, E.S., 1992. Malmquist indices of productivity growth during the deregulation of Norwegian banking, 1980-89. Scandinavian Journal of Economics 94, 211-228.

Berger, A.N., Mester, L.J., 1997. Inside the black box: What explains differences in the 
efficiencies of financial institutions? Journal of Banking and Finance 21, 895-947.

Berger, A.N., DeYoung, R., 1997. Problem loans and cost efficiency in commercial banks. Journal of Banking and Finance 21, 849-870.

Berger, A.N., Humphrey, D.B., 1997. Efficiency of financial institutions: International survey and directions for future research. European Journal of Operational Research 98, 175-212.European Journal of Operational Research 98, 175-212.

Bhattacharyya, A., Lovell, C.A.K., Sahay, P., 1997. The impact of liberalization on the productive efficiency of Indian commercial banks. European Journal of Operational Research, 98, 332-345.

Bhaumik, S.K., Dimova, R., 2004. How Important is Ownership in a Market with Level Playing Field? The Indian Banking Sector Revisited. Journal of Comparative Economics $32,165-180$.

Casu B, Ferrari, A., Zhao, T., 2013. Regulatory Reform and Productivity Change in Indian Banking. Review of Economics and Statistics 95, 1066-1077.

Chambers R.G., Chung Y.H., Färe R., 1998. Profit, directional distance functions, and Nerlovian efficiency. Journal of Optimization Theory and Applications 98, 351-364.

Chang, T.P., Hu, J.L., Chou, R.Y., Sun, L., 2012. The sources of bank productivity growth in China during 2002-2009: A disaggregation view. Journal of Banking and Finance 36, 1997-2006.

Chen, P.C., Yu, M., Managi, S., Chang, C., 2011. Non-radial directional performance measurement with undesirable outputs. Working Paper, Tohoku University.

Das, A., Ghosh, S., 2006. Financial deregulation and efficiency: an empirical analysis of Indian banks during post-reforms period. Review of Financial Economics 15, 193-221.

Das, A., Shanmugam, K.R., 2004, Efficiency of Indian commercial banks during the reform period. Applied Financial Economics 14, 681-686.

Das, A., Kumbhakar, S.C., 2012. Productivity and efficiency dynamics in Indian banking: An input distance function approach incorporating quality of inputs and outputs. Journal of Applied Econometrics 27, 205-234.

Färe, R., Grosskopf S., Norris M., Zhang Z., 1994. Productivity growth, technical progress and efficiency change in industrialized countries. American Economic Review 84, 66-83. 
Färe, R and Lovell, C.A.K., 1978. Measuring the Technical Efficiency of Production, Journal of Economic Theory 19, 150-162.

Färe, R., Grosskopf, S., Lovell, C.A.K., The Measurement of Efficiency of Production, Kluwer academic Publishers, Boston. 2005.

Färe, R., Grosskopf, S., 2010. Directional distance functions and Slacks-based measures efficiency. European Journal of Operational Research 200, 320-322.

Fernandez, C., Koop G., Steel M., 2002. Multiple-output production with undesirable outputs: An application to nitrogen surplus in agriculture. Journal of the American Statistical Association 97, 432 -442.

Fukuyama, H., Weber, W.L., 2008. Japanese banking inefficiency and shadow pricing. Mathematical and Computer Modelling 71, 1854-1867.

Fukuyama, H. and Weber, W.L., 2009. A directional slacks-based measure of technical inefficiency. Socio-Economic Planning Sciences 43, 274-287.

Fukuyama, H., Sekitani, K., 2012. Decomposing the efficient frontier of the DEA production possibility set into a smallest number of convex polyhedrons by mixed integer programming, European Journal of Operational Research 221, 165-174

Kumbhakar, S.C., Sarkar, S., 2003. Deregulation, ownership and productivity growth in the banking industry: evidence from India. Journal of Money, Credit and Banking 35, 403424.

Herd, R., Koen, V., Patnaik, I., Shah, A., 2011. Financial sector reform in India: Time for a second wave? Economics Department Working Papers, No. 879. OECD, Paris, France.

Mester, L.J., 1996. A study of bank efficiency taking into account risk-preferences. Journal of Banking and Finance 20, 1025-1045.

Narasimham, M., 1991. Report of the committee on financial system. Reserve Bank of India, Mumbai.

Narasimham, M., 1998. Report of the committee on banking sector reforms, Ministry of Finance, New Delhi.

Park, K., Weber, W., 2006. A note on efficiency and productivity growth in the Korean banking industry, 1992-2002. Journal of Banking and Finance 30, 2371-2386.

Sahoo, B.K., Tone, K., 2009. Decomposing capacity utilization in data envelopment analysis: An application to banks in India. European Journal of Operational Research 195, 575-594. 
Sanyal, P., Shankar, R., 2011. Ownership, competition, and bank productivity: An analysis of Indian banking in the post-reform period. International Review of Economics and Finance 20, 225-247.

Sarkar, J., Bhaumik, S.K., 1998. Deregulation and the limits to banking sector competition: Some insights from India. International Journal of Development Banking 16, 29-42.

Sarkar, S., Sarkar, J., Bhaumik, S.K., 1998. Does ownership always matter? Evidence from Indian banking industry. Journal of Comparative Economics 26, 262-281.

Sensarma, R., 2006. Are foreign banks always the best? Comparison of state-owned, private and foreign banks in India, Economic Modelling 23, 717-735.

Sensarma, R., 2008. Deregulation, ownership, and profitability performance of banks: evidence from India. Applied Financial Economics 18, 1581-1595.

Tabak, B.M., Tecles, P.L., 2010. Estimating a Bayesian stochastic frontier for the Indian banking system. International Journal of Production Economics 125, 96-110.

Zhou, P., Poh, K.L., Ang, B.W., 2007. A non-radial DEA approach to measuring environmental performance. European Journal of Operational Research, 178, 1-9.

Williams, J., 2004. Determining management behaviour in European banking. Journal of Banking and Finance 28, 2427-2460. 
Table1

Data description

\begin{tabular}{ccccccc}
\hline year & Fix Asset & Deposits & Employee & Loans & OEA & NPL \\
\hline 2004 & 4,028 & 255,651 & 13,027 & 146,230 & 14,284 & 4,224 \\
2005 & 4,308 & 298,063 & 13,260 & 199,032 & 14,895 & 3,520 \\
2006 & 4,699 & 365,206 & 13,826 & 265,151 & 18,986 & 2,813 \\
2007 & 5,667 & 459,623 & 14,358 & 331,043 & 24,051 & 3,175 \\
2008 & 8,320 & 553,529 & 15,071 & 406,952 & 33,055 & 3,573 \\
2009 & 9,097 & 661,250 & 15,294 & 488,028 & 45,772 & 4,692 \\
2010 & 9,179 & 783,216 & 15,516 & 561,364 & 36,603 & 5,834 \\
2011 & 10,155 & 102,018 & 16,389 & 707,869 & 46,842 & 6,023 \\
\hline
\end{tabular}

Table 2

Average inefficiency score by variable from 2004 to 2011

\begin{tabular}{llccccccc}
\hline & & Fix Asset & Deposit & Employee & Loan & OEA & NPL & Inefficiency \\
\hline \multirow{2}{*}{2004} & Average & 0.049 & 0.306 & 0.552 & 0.030 & 1.858 & 0.598 & 0.615 \\
& Std. & $(0.141)$ & $(0.201)$ & $(0.341)$ & $(0.091)$ & $(1.691)$ & $(0.345)$ & $(0.390)$ \\
2005 & Average & 0.127 & 0.148 & 0.387 & 0.715 & 3.322 & 0.539 & 0.926 \\
& Std. & $(0.220)$ & $(0.169)$ & $(0.265)$ & $(0.592)$ & $(2.597)$ & $(0.341)$ & $(0.588)$ \\
2006 & Average & 0.157 & 0.104 & 0.354 & 0.627 & 3.187 & 0.687 & 0.933 \\
& Std. & $(0.230)$ & $(0.141)$ & $(0.230)$ & $(0.416)$ & $(2.336)$ & $(0.322)$ & $(0.520)$ \\
2007 & Average & 0.007 & 0.144 & 0.425 & 0.148 & 2.890 & 0.558 & 0.757 \\
& Std. & $(0.030)$ & $(0.156)$ & $(0.225)$ & $(0.247)$ & $(2.771)$ & $(0.317)$ & $(0.509)$ \\
2008 & Average & 0.015 & 0.090 & 0.324 & 0.016 & 4.603 & 0.168 & 0.874 \\
& Std. & $(0.065)$ & $(0.117)$ & $(0.279)$ & $(0.063)$ & $(4.198)$ & $(0.216)$ & $(0.720)$ \\
2009 & Average & 0.014 & 0.012 & 0.215 & 0.001 & 5.343 & 0.031 & 0.928 \\
& Std. & $(0.065)$ & $(0.032)$ & $(0.218)$ & $(0.007)$ & $(5.164)$ & $(0.091)$ & $(0.874)$ \\
2010 & Average & 0.019 & 0.016 & 0.222 & 0.000 & 3.248 & 0.054 & 0.588 \\
& Std. & $(0.074)$ & $(0.035)$ & $(0.232)$ & $(0.000)$ & $(3.250)$ & $(0.136)$ & $(0.563)$ \\
2011 & Average & 0.026 & 0.189 & 0.091 & 0.017 & 2.617 & 0.305 & 0.575 \\
& Std. & $(0.105)$ & $(0.285)$ & $(0.133)$ & $(0.070)$ & $(2.340)$ & $(0.306)$ & $(0.456)$ \\
\hline
\end{tabular}


Table 3

Average inefficiency score by variables and three groups

\begin{tabular}{ccccccccc}
\hline & year & Fix Asset & Deposit & Employee & Loan & OEA & NPL & Inefficiency \\
\hline \multirow{6}{*}{ National } & 2004 & 0.000 & 0.385 & 0.692 & 0.026 & 1.646 & 0.611 & 0.602 \\
bank & 2005 & 0.055 & 0.185 & 0.501 & 0.801 & 3.384 & 0.541 & 0.960 \\
& 2006 & 0.086 & 0.144 & 0.472 & 0.668 & 3.634 & 0.748 & 1.044 \\
& 2008 & 0.000 & 0.211 & 0.539 & 0.146 & 3.792 & 0.673 & 0.964 \\
& 2009 & 0.032 & 0.079 & 0.323 & 0.003 & 6.384 & 0.145 & 1.160 \\
& 2010 & 0.012 & 0.020 & 0.222 & 0.000 & 4.930 & 0.053 & 0.868 \\
Private & 0.008 & 0.076 & 0.025 & 0.014 & 3.059 & 0.435 & 0.669 \\
\hline bank & 2004 & 0.088 & 0.299 & 0.573 & 0.041 & 2.361 & 0.694 & 0.738 \\
& 2005 & 0.206 & 0.141 & 0.395 & 0.818 & 4.266 & 0.650 & 1.146 \\
& 2006 & 0.242 & 0.083 & 0.346 & 0.721 & 3.710 & 0.788 & 1.076 \\
& 2009 & 0.017 & 0.123 & 0.444 & 0.197 & 2.891 & 0.618 & 0.785 \\
& 2010 & 0.013 & 0.119 & 0.406 & 0.034 & 4.189 & 0.211 & 0.834 \\
Foreign & 2011 & 0.052 & 0.269 & 0.181 & 0.026 & 2.815 & 0.217 & 0.602 \\
\hline \multirow{6}{*}{ bank } & 2007 & 0.000 & 0.000 & 0.000 & 0.000 & 0.000 & 0.000 & 0.000 \\
& 2008 & 0.000 & 0.033 & 0.066 & 0.000 & 0.224 & 0.105 & 0.083 \\
& 2009 & 0.000 & 0.000 & 0.000 & 0.000 & 0.000 & 0.000 & 0.000 \\
& 2005 & 0.081 & 0.074 & 0.036 & 0.008 & 0.930 & 0.246 & 0.260 \\
& 2010 & 0.000 & 0.000 & 0.072 & 0.000 & 0.575 & 0.000 & 0.104 \\
& 2011 & 0.000 & 0.295 & 0.020 & 0.000 & 0.569 & 0.170 & 0.187 \\
\hline
\end{tabular}


Table 4

Difference of inefficiency among bank group

\begin{tabular}{rrrrrl}
\hline & \multirow{2}{*}{ National } & \multirow{2}{*}{ Private } & \multirow{2}{*}{ Foreign } & \multicolumn{3}{c}{ Kruskal-Wallis test } \\
& & & & \multicolumn{1}{c}{ sig } \\
\hline Fix Asset & 0.027 & 0.081 & 0.038 & 8.62 & $* *$ \\
Deposit & 0.138 & 0.135 & 0.062 & 13.77 & $* * *$ \\
Employee & 0.369 & 0.366 & 0.024 & 57.68 & $* * *$ \\
Loan & 0.207 & 0.230 & 0.039 & 10.54 & $* * *$ \\
OEA & 4.207 & 3.520 & 0.311 & 63.73 & $* * *$ \\
NPL & 0.401 & 0.415 & 0.109 & 26.33 & $* * *$ \\
Inefficiency & 0.929 & 0.828 & 0.108 & 65.58 & $* * *$ \\
\hline
\end{tabular}

$* *$, *** represent $5 \%$ and $1 \%$ significant level

Table 5

Difference of productivity change indicators from 2004 to 2011 among bank group

\begin{tabular}{|c|c|c|c|c|c|c|}
\hline & & National & Private & Foreign & $\chi^{2}$ & sig \\
\hline \multirow{7}{*}{ TFP } & Fix Asset & -0.023 & 0.009 & 0.004 & 3.08 & \\
\hline & Deposit & 0.057 & 0.031 & 0.035 & 0.54 & \\
\hline & Employee & 0.080 & 0.071 & 0.021 & 13.59 & $* * *$ \\
\hline & Loan & 0.095 & 0.055 & 0.019 & 7.98 & $* *$ \\
\hline & OEA & 0.331 & 0.476 & 0.076 & 1.62 & \\
\hline & NPL & 0.010 & -0.022 & -0.149 & 0.33 & \\
\hline & total & 0.087 & 0.093 & -0.027 & 1.71 & \\
\hline \multirow{7}{*}{ TECHCH } & Fix Asset & -0.022 & 0.003 & -0.008 & 1.41 & \\
\hline & Deposit & 0.013 & 0.026 & 0.067 & 2.24 & \\
\hline & Employee & -0.015 & 0.015 & 0.019 & 2.36 & \\
\hline & Loan & 0.093 & 0.053 & 0.018 & 0.59 & \\
\hline & OEA & 0.532 & 0.540 & 0.024 & 1.08 & \\
\hline & NPL & -0.015 & -0.09 & -0.159 & 3.66 & \\
\hline & Total & 0.097 & 0.074 & -0.037 & 0.85 & \\
\hline \multirow{7}{*}{ EFFCH } & Fix Asset & -0.001 & 0.005 & 0.012 & 0.19 & \\
\hline & Deposit & 0.044 & 0.004 & -0.032 & 3.60 & \\
\hline & Employee & 0.095 & 0.056 & 0.002 & 10.09 & $* * *$ \\
\hline & Loan & 0.002 & 0.002 & 0.001 & 1.65 & \\
\hline & OEA & -0.202 & -0.065 & 0.052 & 0.03 & \\
\hline & NPL & 0.025 & 0.068 & 0.011 & 1.42 & \\
\hline & total & -0.010 & 0.019 & 0.010 & 0.02 & \\
\hline
\end{tabular}


Table 6

Innovators by bank groups

\begin{tabular}{cccccc}
\hline & & $\begin{array}{c}\text { All banks } \\
(\mathrm{N}=37)\end{array}$ & $\begin{array}{c}\text { National banks } \\
(\mathrm{N}=16)\end{array}$ & $\begin{array}{c}\text { Private banks } \\
(\mathrm{N}=16)\end{array}$ & $\begin{array}{c}\text { Foreign banks } \\
(\mathrm{N}=5)\end{array}$ \\
\hline & $2004-2005$ & 1 & 0 & 0 & 1 \\
Innovator of & $2005-2006$ & 2 & 0 & 0 & 2 \\
total factor & $2006-2007$ & 3 & 0 & 0 & 3 \\
productivity & $2007-2008$ & 3 & 0 & 0 & 3 \\
(Innovator) & $2008-2009$ & 2 & 1 & 0 & 1 \\
& $2009-2010$ & 2 & 1 & 1 & 0 \\
& $2010-2011$ & 0 & 0 & 0 & 0 \\
\hline & $2004-2005$ & 0 & 0 & 0 & 0 \\
Innovator of & $2005-2006$ & 1 & 0 & 0 & 1 \\
input and & $2006-2007$ & 2 & 0 & 0 & 2 \\
goods use & $2007-2008$ & 4 & 0 & 0 & 4 \\
(Innovator $x, y)$ & $2008-2009$ & 2 & 1 & 0 & 1 \\
& $2009-2010$ & 1 & 1 & 0 & 0 \\
& $2010-2011$ & 0 & 0 & 0 & 0 \\
\hline Innovator of & $2004-2005$ & 2 & 1 & 0 & 1 \\
NPLs & $2005-2006$ & 2 & 0 & 0 & 2 \\
treatment & $2007-2007$ & 1 & 0 & 0 & 1 \\
(Innovator $\left.{ }_{b}\right)$ & $2008-2009$ & 2 & 0 & 0 & 0 \\
& $2009-2010$ & 2 & 0 & 0 & 1 \\
& $2010-2011$ & 0 & 0 & 0 & 1 \\
\hline & & & & & 0 \\
\hline
\end{tabular}


Figure 1

TFP change from 2004 to 2011 by each input/output variable

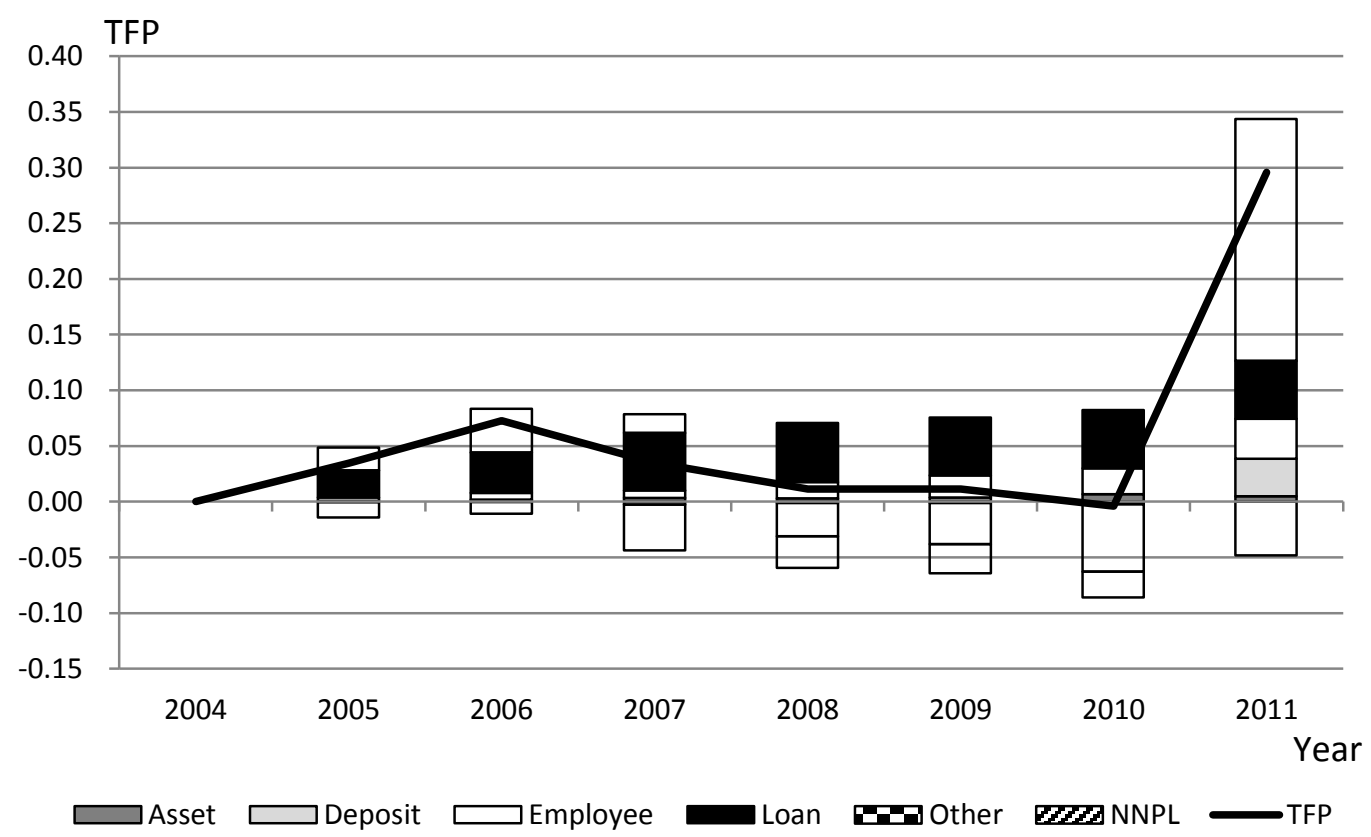

Figure 2

TECHCH change from 2004 to 2011 by each input/output variables

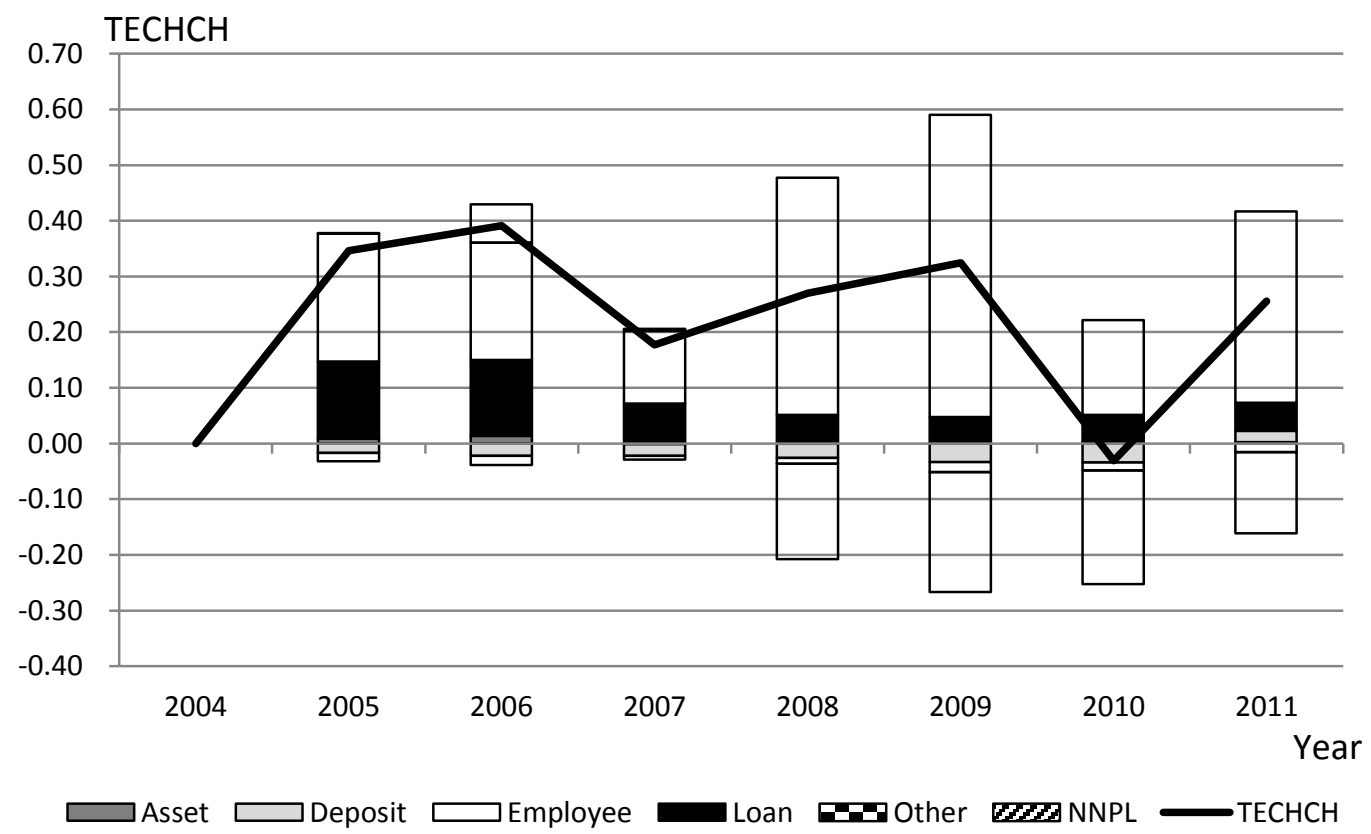


Figure 3

EFFCH change from 2004 to 2011 by each input/output variables

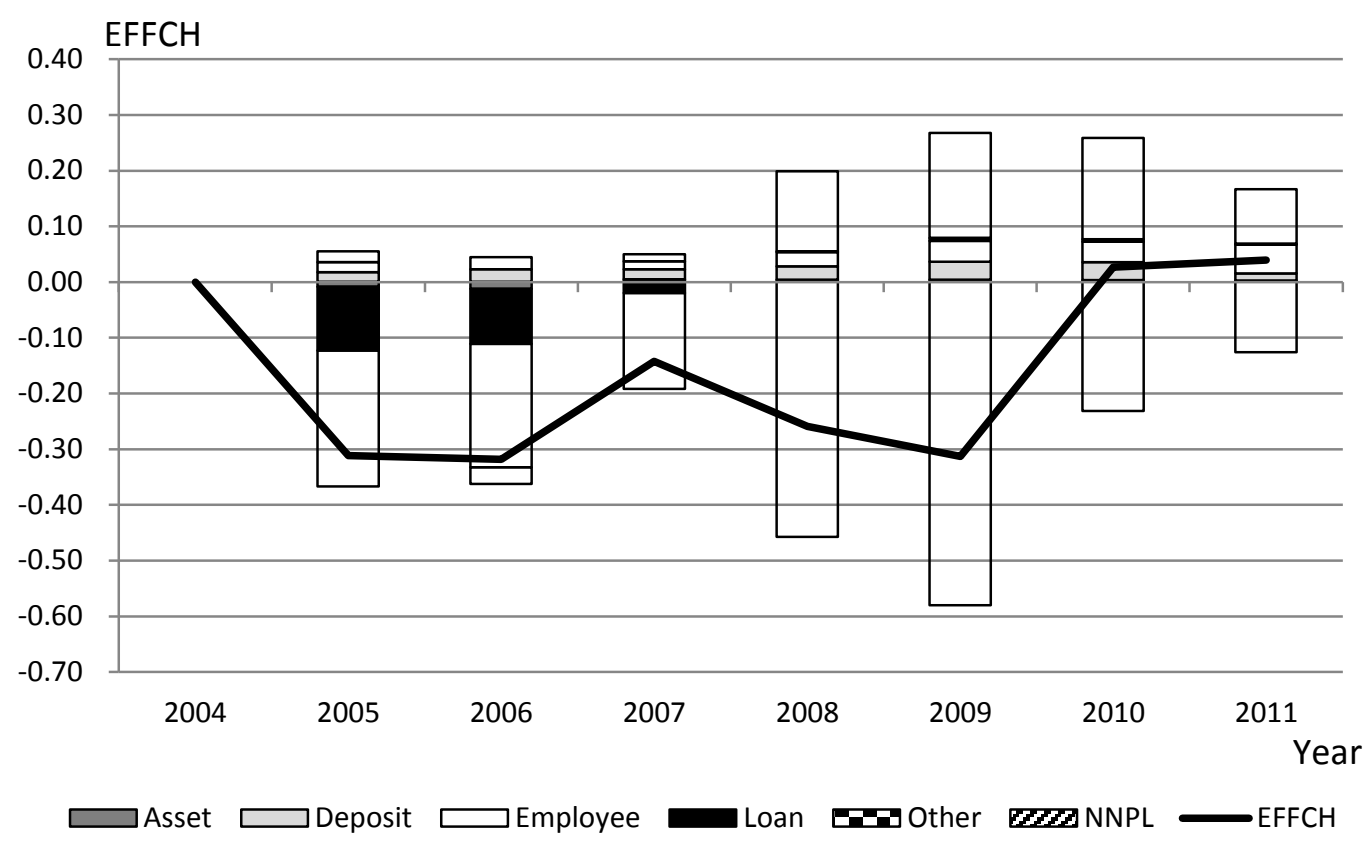

